\title{
Efektifitas Jamur Metharhizium anisopliae Menghambat Perkembangan Hama Uret pada Tanaman Cincau Hitam (Mesona palustris BL)
}

\author{
Wuye Ria Andayanie \\ Dosen Fakultas Pertanian, Universitas Merdeka Madiun, Jl. Serayu No. 79, Madiun, 63133 \\ E-mail: wuyeria@unmer-madiun.ac.id
}

\begin{abstract}
Black grass jelly plants can be used as conservation plants. However, uret pests (Leucopholis rorida F.) are often complained that eat the base of the stems, flowers and roots at night. This study aims to determine: 1) the effect of $M$. anisopliae fungi on uret pests, (2) the level of susceptibility of uret pests, and (3) M. anisopliae fungal effectiveness on uret pests. This study used a completely randomized design (CRD) with 4 treatments and 5 replications. Data from the observations were analyzed using analysis of variance (ANOVA) with Duncan's Multiple Range Test (DMRT) 5\% test carried out when diversity analysis showed a real effect. Uret mortality monitoring will be carried out after the application of fungi. by observing each uret and calculating the amount of uret mortality and average plant growth. The highest percentage of second instar larvae from uret was found in treatment $P 4$ (manure and fungi were incubated for 72 hours at the next temperature of $28{ }^{\circ} \mathrm{C}$ applied to the field with straw mulch) which was $82,98 \%$ at 12 days after application of fungi. The average growth of plants consisting of: root length, root volume, stem diameter and number of shoots was also found in treatment P4 (manure and fungi were incubated for 72 hours at the next 28 oC, applied to the field with straw mulch), respectively amounting to $12.45 ; 5.70 ; 1.88 ; 12,15$. Dead larvae emit fluids such as ethanol and their bodies are weak, then the body dries and hardens and stiffens, like mummies and fungi forming green sporulation.
\end{abstract}

Keywords—: black grass jelly plants; Leucopholis rorida F; Metharhizium anisopliae; mortality; effectiveness.

\section{PENDAHULUAN}

Budidaya cincau hitam atau janggelan (Mesona palustris BL) mempunyai peluang untuk ditanam di lahan berlereng, meskipun lahan berlereng rentan terhadap longsor dan erosi. Hal ini karena tanaman cincau hitam dapat digunakan sebagai tanaman konservasi dan sering dijumpai tumbuh secara liar.

Tanaman ini dapat tumbuh dengan baik tanpa pupuk kimia dan dapat dipanen hingga beberapa kali. Selain itu mempunyai perakaran lebat yang sifatnya mengikat tanah, sehingga dapat ditanam di galengan teras atau tempat berlereng dan memiliki kemampuan untuk dapat hidup pada kondisi kering yang tidak subur tanahnya serta sangat menjanjikan saat musim kemarau (Andayanie et al., 2018). Tanaman cincau hitam dapat menyerap air dan zat-zat makanan melalui akar yang berupa rambut akar, dan berbentuk serabut. Sehingga penyerapan akar menjadi luas (Yasid et al., 2016).

Hama uret (Leucopholis rorida) sering dikeluhkan oleh petani cincau hitam dan sulit dikendalikan karena hidupnya di dalam tanah dan mengadakan kegiatan memakan pangkal batang,bunga dan akar pada malam hari. Kerusakan akar dapat mengakibatkan daun tanaman menguning atau pada tanaman cincau hitam daun berubah warna menjadi keunguan dan menyebabkan kematian pada tanaman (Saragih, 2009). Menurut Lee \& Hou (2003) kerusakan pada tanaman akan menghambat aliran zat hara dan menyebabkan terjadinya kelayuan pada tanaman muda. Umumnya petani mengatasi serangan hama dengan pestisida. Namun dampak pestisida menyebabkan resurgensi, resistensi dan ledakan hama sekunder serta matinya musuh alami. Oleh karena itu salah satu alternatif mengendalikan hama uret dengan pemanfaatan agen hayati yang lebih ramah lingkungan. Agens hayati Metarhizium anisopliae dapat menggantikan fungsi pestisida kimia dan mempunyai inang yang luas (Diedhiou et al., 2014). Jamur ini sering disebut Green muscardine fungus.

Kemampuan entomopatogen M. anisopliae memiliki racun cyclic peptide yang disebut destruxin, yang merupakan bahan insektisida generasi baru. Efek destruxin berpengaruh pada organ sel target yang menyebabkan tubulus malphigi, paralisa sel, kelainan fungsi lambung tengah, hemocyt dan jaringan otot pada inang (Tampubolon et al., 2013). Jamur M. anisopliae telah lama digunakan sebagai agen hayati dan dapat menginfeksi jenis serangga dari golongan Hemiptera dan Coleoptera, Lepidoptera, Homoptera dan Isoptera (Prayogo et al., 2012; Suprayogi et al., 2015). Serangga yang terserang jamur M.anisopliae ini memiliki gejala tidak mau makan, tubuh menjadi lemah, dan kurang orientasi, lama kelamaan diam, dan pada akhirnya serangga terbunuh.

Spora jamur yang masuk dalam tubuh serangga akan membentuk hifa lateral dari jaringan epidermis, sehingga seluruh tubuh serangga dipenuhi oleh hifa, dan berkembangbiak membuat cairan dalam tubuh serangga serta akan habis diserap oleh cendawan. Pertumbuhan hifa di dalam tubuh serangga akan dilanjutkan dengan penampakan serangga seperti terselimuti oleh bulu halus berwarna putih dan berubah warna menjadi hijau tua, kemudian serangga akan mengeras kaku seperti mumi (Tkaczuk et al., 2014). 
Website : http://agritek.unmermadiun.ac.id/index.php/agritek

Namun demikian aplikasi di lapangan menghadapi beberapa kendala antara lain: temperatur, masalah penyiapan, tidak tahan lama disimpan dan biayanya mahal jika lingkungan belum stabil, mematikan serangga penyerbuk. (Deciyanto et al., 2005; Schranka \& Vainstein, 2010). Oleh karena itu perlakuan jamur entomopatogen sebaiknya dilakukan pada sore hari untuk menghindari radiasi sinar ultra violet dan kelembapan yang tinggi, sehingga mampu meningkat efektifitas jamur pathogen serta konsentrasi yang aman untuk serangga bukan sasaran.

Penelitian mengenai efikasi jamur entomopatogen M. anisopliae di Indonesia masih sedikit terutama terhadap serangan hama uret pada tanaman cincau hitam. Oleh karena itu perlu diketahui efektifitas jamur M. anisopliae terhadap mortalitas hama uret dan pertumbuhan tanaman cincau hitam.

\section{METODE PENELITIAN}

Penelitian ini dilaksanakan di Greenhouse dan Laboratorium Pengamatan Hama dan Penyakit Tanaman Pangan dan Hortikultura (PHPTPH) Desa Kedungrejo, Kecamatan Pilangkenceng, Kabupaten Madiun. Waktu penelitian dimulai bulan September - Desember 2018.

\section{A. Metode Penelitian}

Penelitian ini menggunakan Rancangan Acak Lengkap (RAK) non faktorial dengan 5 Perlakuan dan 5 ulangan yang terdiri atas:

$\mathrm{P} 0=$ kontrol

$\mathrm{P} 1=$ aplikasi pupuk kandang di lapangan, 72 jam berikutnya aplikasi $M$. anisopliae,

P2 = aplikasi pupuk kandang di lapangan, 72 jam berikutnya aplikasi $M$. anisopliae dan mulsa jerami,

$\mathrm{P} 3=$ aplikasi pupuk kandang, M. anisopliae diinkubasikan selama 72 jam pada suhu $28{ }^{\circ} \mathrm{C}$, selanjutnya diaplikasikan ke lapangan,

$\mathrm{P} 4=$ aplikasi pupuk kandang, $M$. anisopliae diinkubasikan selama 72 jam pada suhu $28{ }^{\circ} \mathrm{C}$, selanjutnya diaplikasikan ke lapangan dengan mulsa jerami.

Pengamatan dilakukan secara destruktif. Data hasil pengamatan dianalisis dengan menggunakan analisis sidik ragam (ANOVA) dengan uji lanjut Duncan Multiple Range Test (DMRT) 5\% dilakukan apabila analisis keragaman menunjukkan pengaruh yang nyata. Tingkat efikasi jamur M. anisopliae dilakukan pengamatan terhadap mortalitas uret pada 3, 6, 9 dan 12 hari setelah aplikasi jamur M. anisopliae dengan rumus Abbott, bila larva pada kontrol ada yang mati (Abbott, 1925; Senewe et al., 2015).

Keterangan:

$$
\mathrm{P}=(\mathrm{Po}-\mathrm{Pc}) /(100-\mathrm{Pc}) \times 100 \%
$$

$\mathrm{P}=$ persentase mortalitas terkoreksi

Po $=$ persentase mortalitas dalam perlakuan

$\mathrm{Pc}=$ persentase mortalitas dalam kontrol

Formula Abbott ini akan dilakukan penyesuaian untuk memperkirakan kematian secara alami. Apabila kematian kontrol mencapai $20 \%$ maka perlakuan diulang.

Pertumbuhan tanaman cincau hitam diamati berdasarkan pada panjang akar, volume akar, diameter batang, dan jumlah tunas.

\section{B. Pelaksanaan Penelitian}

\section{1) Penyiapan media tanam:}

Tabel: Tanah diambil dari sekitar green house dan disterilkan agar terhindar dari hama penyakit. Selanjutnya tanah dicampur dengan kompos 2:1 dan dimasukkan kira-kira 2/3 bagian. Kompos yang digunakan sudah terdekomposisi sempurna.

2) Penyediaan bibit:

Bibit cincau diambil dari Kabupaten Wonogiri. Bibit janggelan diambil dari anakan rumpun tanaman janggelan yang telah tua dan akarnya sudah ada serta tingginya antara $15-20 \mathrm{~cm}$. Bibit dari anakan dapat langsung ditanam di dalam polibag.

3) Pengambilan hama Leucopholis rorida:

Perbanyakan serangga uji dilakukan dengan pengambilan telur. Pengambilan telur L. rorida diperoleh dari Desa Bugelan, Kecamatan Kismantoro, Kabupaten Wonogiri. Telur dimasukkan ke dalam toples yang berisi tanah dan akar tanaman cincau hitam hingga menetas. Akar tanaman cincau hitam yang masih segar diberikan selama pemeliharaan dan diganti setiap 2 hari sekali hingga larva instar ke-1 mengalami pergantian kulit menjadi larva instar ke-2. Larva instar ke-2 yang telah dilaparkan selama 24 jam, selanjutnya dipindahkan ke tanaman cincau hitam yang berumur 10 hari. Setiap polibag diisi dua larva dan tanah ditutup dengan jerami sesuai perlakuan. Selanjutnya tanah ditutup dengan mulsa jerami sesuai dengan perlakuan.

4) Perbanyakan jamur Metarhizium anisopliae:

Jamur M. anisopliae diperbanyak dengan media beras. Media beras dicuci bersih dan dikukus sekitar 15- 20 menit. Media diangkat dan di kering anginkan. Media dimasukkan ke dalam plastik tahan panas. Tiap plastik berisi 200 gram beras dan di ikat. Media di sterilkan dalam autoklaf dengan temperatur $120{ }^{\circ} \mathrm{C}$ selama 30 menit. Media yang telah 
Website : http://agritek.unmermadiun.ac.id/index.php/agritek

dingin diisolasi dengan jamur M. anisopliae menggunakan pinset dan dilakukan di dalam inkas sebanyak 10 gram per plastik serta diinkubasi selama 14 hari.

5) Aplikasi Metarhizium anisopliae:

Aplikasi jamur M. anisopliae pada tanaman cincau hitam dilakukan sore hari saat tanaman berumur 14 hari. Suspensi konidia jamur $M$. anisopliae dengan kerapatan $10^{10}$ disemprotkan ke tanaman dan tanah sebanyak 50 ml untuk setiap perlakuan.

\section{III.HASIL DAN PEMBAHASAN}

\section{A. Mortalitas Larva Instar Ke-2 Leucopholis rorida L.}

Pengamatan hari ke-1 hingga ke-2 setelah aplikasi jamur $M$. anisopliae belum dijumpai kematian pada larva $L$. rorida. Spora jamur memerlukan waktu untuk membentuk hifa lateral dan menembus serta berkembangbiak di dalam jaringan epidermis pada kulit dan ruas tubuh larva. Tubuh larva mulai ditumbuhi oleh hipha berwarna putih pada hari ke-3 setelah aplikasi $M$. anisopliae dan menimbulkan infeksi hingga mengeluarkan cairan dalam tubuh larva. Menurut Hasnah et al. (2012) enzim lipolitik, proteolitik dan kitinase menyebabkan tubuh serangga mengalami hidrolisis.

Larva L. rorida akan memakan akar tanaman cincau hitam sampai 12 has. Hasil analisis sidik ragam pengamatan 12 hari setelah aplikasi (hsa) menunjukkan mortalitas terendah pada perlakuan aplikasi pupuk kandang di lapangan, 72 jam berikutnya aplikasi $M$ anisopliae (P1) (Tabel 1).

Tabel 1. Mortalitas larva instar ke-2 Leucopholis rorida $\mathrm{L}$.

\begin{tabular}{lrrrr}
\hline Perlakuan & \multicolumn{4}{c}{ Hari setelah aplikasi } \\
\cline { 2 - 5 } & $\mathbf{3}$ & $\mathbf{6}$ & $\mathbf{9}$ & $\mathbf{1 2}$ \\
\hline P0 & $0,94 \mathrm{c}$ & $1,05 \mathrm{c}$ & $1,80 \mathrm{e}$ & $2,01 \mathrm{e}$ \\
P1 & $1,25 \mathrm{c}$ & $2,49 \mathrm{c}$ & $5,01 \mathrm{~d}$ & $14,60 \mathrm{~d}$ \\
P2 & $3,01 \mathrm{c}$ & $8,25 \mathrm{bc}$ & $18,12 \mathrm{c}$ & $30,75 \mathrm{c}$ \\
P3 & $8,70 \mathrm{~b}$ & $19,82 \mathrm{~b}$ & $30,95 \mathrm{~b}$ & $75,32 \mathrm{~b}$ \\
P4 & $18,63 \mathrm{a}$ & $34,46 \mathrm{a}$ & $48,07 \mathrm{a}$ & $82,98 \mathrm{a}$ \\
\hline
\end{tabular}

Keterangan: Angka yang diikuti oleh huruf yang sama pada kolom yang sama tidak berbeda nyata pada uji lanjut Duncan Multiple Range Test (DMRT) 5\%. P0: kontrol; P1: aplikasi pupuk kandang di lapangan, 72 jam berikutnya aplikasi $M$. anisopliae; P2 : aplikasi pupuk kandang di lapangan, 72 jam berikutnya aplikasi M. anisopliae dan mulsa jerami; P3: pupuk kandang dan $M$. anisopliae diinkubasikan selama 72 jam pada suhu $28{ }^{\circ} \mathrm{C}$ berikutnya diaplikasikan ke lapangan; P4: pupuk kandang dan M. anisopliae diinkubasikan selama 72 jam pada suhu $28{ }^{\circ} \mathrm{C}$ berikutnya diaplikasikan ke lapangan dengan mulsa jerami.

Larva $L$. rorida akan dipenuhi kumpulan hipha atau miselium yang berwarna putih terutama pada ruas-ruas tubuhnya dan semakin lama berwarna hijau serta larva mengeras seperti mummi seperti ditunjukkan pada Gambar 1.

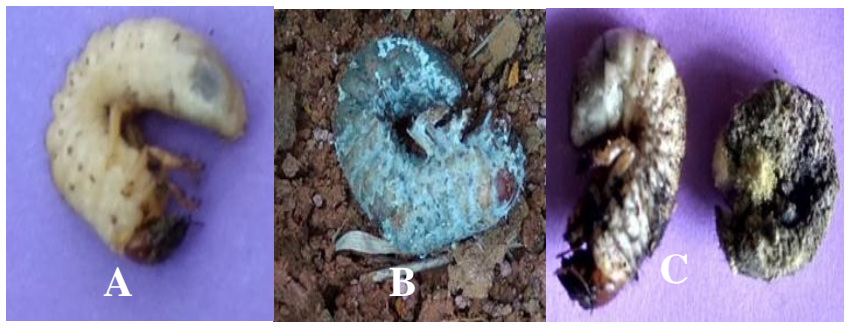

Gambar 1. Tahapan gejala kematianl larva L. rorida instar ke-2. A: larva instar ke -2 sehat; B: tubuh larva instar ke-2 telah terinokulasi dengan M. anisopliae 3: tubuh larva instar ke-2 mulai menjadi mummi dan mummi larva instar ke-2.

\section{B. Pertumbuhan Tanaman Cincau Hitam (Mesona palustris BL.)}

Hasil analisis sidik ragam menunjukkan aplikasi jamur $M$. anisopliae berpengaruh nyata antar perlakuan terhadap rerata panjang akar, volume akar, diameter batang, jumlah tunas (Tabel 2).

Tabel 2. Rataan pertumbuhan tanaman cincau hitam

\begin{tabular}{ccccc}
\hline Perlakuan & $\begin{array}{c}\text { Panjang } \\
\text { akar } \\
(\mathbf{c m})\end{array}$ & $\begin{array}{c}\text { Volume } \\
\text { akar } \\
(\mathbf{m l})\end{array}$ & $\begin{array}{c}\text { Diameter } \\
\text { batang } \\
(\mathbf{c m})\end{array}$ & $\begin{array}{c}\text { Jumlah } \\
\text { tunas }\end{array}$ \\
P0 & $4,97 \mathrm{c}$ & $1,45 \mathrm{c}$ & $0,82 \mathrm{~d}$ & $3,89 \mathrm{~b}$ \\
P1 & $6,28 \mathrm{bc}$ & $2,84 \mathrm{~b}$ & $0,98 \mathrm{~d}$ & $4,95 \mathrm{~b}$ \\
P2 & $8,35 \mathrm{abc}$ & $3,01 \mathrm{~b}$ & $1,35 \mathrm{c}$ & $5,25 \mathrm{~b}$ \\
P3 & $11,23 \mathrm{ab}$ & $5,67 \mathrm{a}$ & $1,69 \mathrm{~b}$ & $7,68 \mathrm{ab}$ \\
P4 & $12,45 \mathrm{a}$ & $5,70 \mathrm{a}$ & $1,88 \mathrm{a}$ & $12,15 \mathrm{a}$ \\
\hline
\end{tabular}

Keterangan: Angka yang diikuti oleh huruf yang sama pada kolom yang sama tidak berbeda nyata pada uji lanjut Duncan Multiple Range Test (DMRT) 5\%. P0: kontrol; P1: aplikasi pupuk kandang di lapangan, 72 jam berikutnya aplikasi M. anisopliae; P2 : aplikasi pupuk kandang di lapangan, 72 jam berikutnya aplikasi M. anisopliae dan mulsa jerami; P3: pupuk kandang dan M. anisopliae diinkubasikan 
Website : http://agritek.unmermadiun.ac.id/index.php/agritek

selama 72 jam pada suhu 28 oC berikutnya diaplikasikan ke lapangan; P4: pupuk kandang dan M. anisopliae diinkubasikan selama 72 jam pada suhu 28 oC berikutnya diaplikasikan ke lapangan dengan mulsa jerami.

Penggunaan jamur M. anisopliae memberikan peningkatan terhadap pertumbuhan tanaman akibat serangan uret. Aplikasi $M$. anisopliae setelah diinkubasikan selama 72 jam (P1) menunjukkan perbedaan yang nyata dibandingkan jika M. anisopliae langsung diaplikasikan di lapangan, seperti yang diperlihatkan pada Gambar 2.

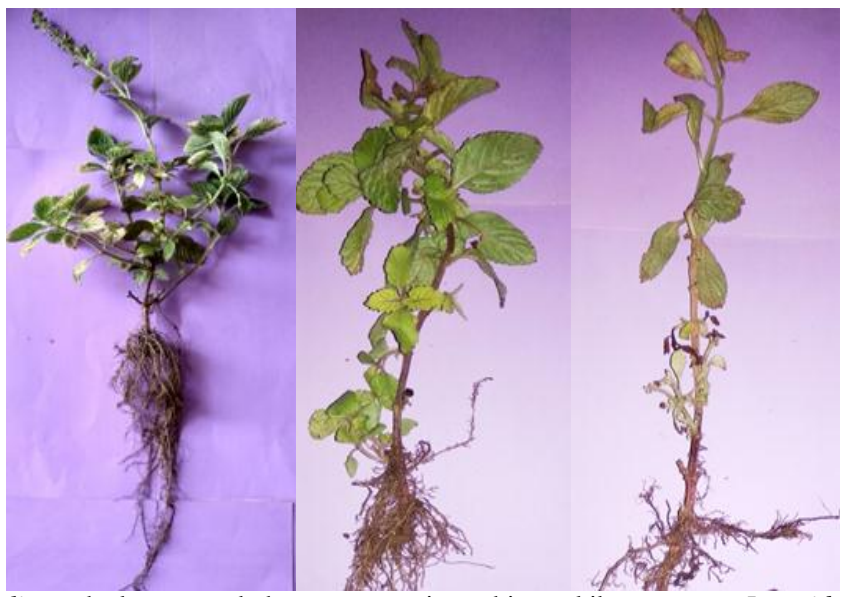

Gambar 2. Penggunaan jamur M. anisopliae terhadap pertumbuhan tanaman cincau hitam akibat serangan L. rorida. A: aplikasi jamur M. anisopliae setelah diinkubasikan selama 72 jam; B: aplikasi jamur M. anisopliae langsung diaplikasikan ke pertanaman; C: aplikasi tanpa jamur M. anisopliae.

Akar merupakan pusat organ tumbuhan yang memiliki fungsi utama untuk menghisap air dan garam mineral dari dalam tanah. Akar yang terluka mengakibatkan unsur hara terganggu dan terjadi declaration xilem. Jika fungsi xilem terganggu maka fotosintesis pun akan terganggu, mengakibatkan pertumbuhan tanaman, antara lain panjang akar, volume akar, diameter batang, jumlah tunas berkurang. Pertumbuhan jumlah tunas dipengaruhi oleh pertumbuhan akar dan mempengaruhi pertumbuhan jumlah daun, semakin banyak tunas maka akan semakin banyak daun yang tumbuh. Sehingga proses fotosintesis dan respirasi berjalan lancar. Pernyataan ini diperkuat dengan penelitian Senditya et al.(2014) bahwa laju pertumbuhan diameter batang pada tanaman akan sejalan dengan laju efektifitas dari fotosintesis, erat kaitannya dengan jumlah unsur hara yang masuk karena akan mempengaruhi diameter atau tinggi serta morfologi tanaman secara keseluruhan.

Pola pengendalian hama uret $(L$. rorida) pada tanaman cincau hitam dengan paket teknologi pupuk kandang dan $M$. anisopliae diinkubasikan selama 72 jam pada suhu $28^{\circ} \mathrm{C}$ berikutnya diaplikasikan ke lapangan dengan mulsa jerami dapat diterapkan ke petani karena dapat mempertahankan pertumbuhan tanaman cincau hitam. Hal ini sesuai dengan Pengendalian Hama Terpadu (PHT) yang mempunyai sasaran untuk meningkatkan kuantitas dan kualitas tanaman dari serangan jasad pengganggu dan tetap mempertahankan kualitas lingkungan hidup.

\section{IV.KESIMPULAN}

Perlakuan sebelum aplikasi dilapang menentukan keefektifan jamur $M$. anisopliae. Perlakuan P4 (pupuk kandang dan $M$. anisopliae diinkubasikan selama 72 jam pada suhu $28{ }^{\circ} \mathrm{C}$ berikutnya diaplikasikan ke lapangan dengan mulsa jerami) mempunyai efektifitas tertinggi yaitu sebesar 82, $98 \%$ pada 12 hari setelah aplikasi jamur Mataan pertumbuhan tanaman yang terdiri atas: panjang akar, volume akar, diameter batang dan jumlah tunas terbanyak juga dijumpai perlakuan P4 (pupuk kandang dan $M$. anisopliae diinkubasikan selama 72 jam pada suhu $28{ }^{\circ} \mathrm{C}$ berikutnya diaplikasikan ke lapangan dengan mulsa jerami), masing-masing sebesar 12,45; 5,70; 1,88; 12,15.. Larva yang mati mengeluarkan cairan seperti etanol dan tubuhnya lemas, selanjutnya tubuhnya mengering dan mengeras serta kaku, seperti mummi serta jamur membentuk sporulasi yang berwarna hijau.

\section{UCAPAN TERIMAKASIH}

Ucapan terima kasih disampaikan kepada LPPM Universitas Merdeka Madiun yang telah memfasilitasi dana untuk penelitian intern. Ucapan terimakasih juga disampaikan ke Laboratorium Pengamatan Hama dan Penyakit Tanaman Pangan dan Hortikultura (PHPTPH) Desa Kedungrejo, Kecamatan Pilangkenceng, Kabupaten Madiun yang telah memfasilitasi pelaksanaan penelitian di atas.

\section{VI.DAFTAR PUSTAKA}

Abbott, W.S. (1925). Method for Conperting the Effectiveness Insecticide. J. Econ. Entomol, 18: 265-267.

Andayanie, W.R., Iswati, R. \& Srijani, N. (2018). Teknologi Tepat Guna Budidaya Janggelan Secara Organik pada Lahan Berlereng. Penerbit Pustaka Pranala Yogyakarta.

Deciyanto,S.S.G., Reyes \& Santiago, D.R. (2005). Laboratory assay of Beauveria bassiana isolates against Helicoverpa armigera. Proceedings of the first International Conference of Crop Security. Brawijaya, Malang, 20-22 September 2005:46-55

Hasnah, Susanna \& Sably, H. (2012) Keefektifan Cendawan Beauveria bassiana Vuill terhadap Mortalitas Kepik Hijau Nezara viridula L. pada Stadia Nimfa dan Imago. J. Floratek, 7: 3-14. 
Website : http://agritek.unmermadiun.ac.id/index.php/agritek

Lee, P.C \& Hou, R.F. (2003). Pathogenesis of Metarhizium anisopliae var. anisopliae in The Smaller Brown Plant Hopper Laodhelpax striatelus. J. Entomol. $9: 13-19$.

Yasid, W.A., Respatrijarti \& Damanhuri (2016). Ekplorasi dan Identifikasi Karakter Morfologi Tanaman Cincau Hitam (Mesona palustris BL.) di Pacitan, Magetan, Ponorogo. Jurnal Produksi Tanaman, 4 (4): 306-310.

Prayogo, Y. (2012). Efikasi Cendawan Entomopatogen Beauveria bassiana Bals. Vuill (Deuteromycotina: Hyphomycetes) terhadap Kepik Hijau Nezara viridula (L.). J. Suara Perlindungan Tanaman, 2(1): 27-28.

Saragih, D.M. (2009). Serangan Uret dan Cara Pengendaliannya pada Tanaman Eucalyptus hybrid Di Hutan Tanaman Industri PT. Toba Pulp Lestari Sektor Aek Na Uli Sumatera Utara. Institut Pertanian Bogor.

Schranka, A. \& Vainstein, M.H. (2010). Metharhizium anisopliae Enzymes and Toxins. Toxicon, 56(7): 1267-1274.

Senditya,M., M.S. Hadi, T. Estiasih \& E. Saparianti. 2014. Efek Prebiotik dan Sinbiotik Simplisia Daun Cincau Hitam (MesonaPalustris BL.) Secara In Vivo: Kajian Pustaka. Jurnal Pangan dan Agroindustri. 2 (3): 141-150.

Senewe, E., Maramis, R. \& Salaki, C. (2015). Pemanfaatan Bakteri Entomopatogenik Bacillus cereus terhadap Hama Spodoptera litura pada Tanaman Kubis. Eugenia, 18(2): 134-144

Suprayogi, Marheni \& Oemry, S. (2015). Uji Efektifitas Jamur Entomopatogen Beauveria bassiana dan Metarhizium anisopliae terhadap Kepik Hijau (Nezara viridula L.)(Hemiptera; Pentatomidae) pada Tanaman Kedelai (Glycine max L.) di Rumah Kasa. J. Online Agroteknologi, 3(1): $320-327$.

Tampubulon, D.Y., Y. Pangestiningsih, F. Zahra, \& Manik, F. (2013). Uji Patogenesitas Bacillus thuringiensis dan Metarhizium anisopliae. Terhadap Mortalitas Spodoptera litura Fabr (Lepidoptera: Noctuidae) Di laboratorium.. J.Online agroekoteknologi. 1(3):784-791.

Tkaczuk,C., A. Krol., A. M. Safaryanand, \& Nicewicz,L. (2014). "The occurrence of entomo-pathogenic fungi in soils from field cultivated in a conventional and organic system". Journal of Ecological Engineering, 15, (4).pp. 137-44. 